\title{
Reuse Legacy to Repower the Microgrids-An Affordable Solution for Test and Restoration of Repurposed Lead Acid Batteries
}

\author{
Khadim Ullah Jan* \\ Université Paris-Saclay, CNRS \\ Centrale Supelec GeePs UMR 8507 \\ 91192 Gif sur Yvette, \\ Paris, France \\ khadim.jan@geeps.centralesupelec.fr \\ Waqar Uddin \\ Department of Electrical \& Computer \\ Engineering \\ Pusan National University \\ Busan, South Korea \\ waqudn@pusan.ac.kr
}

\author{
Anne Migan \\ Université Paris-Saclay, CNRS \\ Centrale Supelec GeePs UMR 8507 \\ 91192 Gif sur Yvette, \\ Paris, France \\ anne.migan-dubois@centralesupelec.fr
}

\author{
Mashood Nasir \\ Centre for Research on Microgrids \\ Department of Energy Technology, \\ 9220 Aalburg East, \\ Aalburg, Denmark \\ mnas@et.aau.dk
}

\author{
Demba Diallo \\ Université Paris-Saclay, CNRS \\ Centrale Supelec GeePs UMR 8507 \\ 91192 Gif sur Yvette, \\ Paris, France \\ demba.diallo@centralesupelec.fr \\ Imran Khan \\ Université Paris-Saclay, CNRS \\ C2N UMR 9001 \\ 91120 Palaiseau \\ Paris, France \\ imran.khan@u-psud.fr
}

\begin{abstract}
Initial cost is an important consideration as many problems raised by the insufficient battery capacity had eventually resulted in microgrid failure. The trending use of expensive, but more efficient and maintenance free lithium-ion batteries in millions of light vehicles such as golf carts will decommission a large amount of existing lead acid batteries to be used for electrification purposes at much lower cost. These used batteries in their second life can significantly reduce the storage cost of electrification in off-grid systems or in the most demanding business activities such as powering vendor hand-carts and community shops. Though, the used batteries are sold at cheaper price, they still require costly equipment and time consuming tests to evaluate if and for how long they can be repurposed. This paper is prepared to propose a rapid, low cost, and bulk test procedure for lead acid battery characterization, capacity measurements, and restoration without any of their known history or datasheet using deep cycling process. Parameters are suggested to help in remaining life identification and to qualify these batteries for grouping in power packs based on their health and capacity. Finally, a process to review test results and make appropriate decisions regarding the battery reuse or recycling is provided.
\end{abstract}

Keywords - cost reduction, microgrids, battery testing, second life, lead acid batteries, battery restoration, legacy

\section{INTRODUCTION}

The market of the off-grid renewable or hybrid renewable electrification system is composed of very low income households [1], [2]. Initial cost of the battery bank had remained a major issue in achieving the ambitious target of sustainable energy for all and 24/7 energy access by every citizen and in particular by the poor in the remote locations [3]. This indeed put pressure on lowering the cost of any electrification system proposed for such applications [4]-[6].

It is a known field practice that a lot of common issues with the Photovoltaic (PV) or hybrid PV/diesel grid collapse [7] is the undersized battery storage system [8] to reduce high initial cost. In areas with increased power cut, the shop owners and the poor with vendor carts to sell fruits and vegetables are losing revenues and unable to fulfill their basic needs. In order to reduce the high initial cost on storage for households and electrification services on hand-carts, second life lead acid batteries are considered as a potential solution [9], [10].

This research is sponsored by the Islamic Development Bank (IsDB) under the Agreement No. 600036563 Sustainable Energy \& Power. *As a faculty member of the Department of Electrical Engineering, full support is received from the University of Engineering \& Technology, 23200, Mardan, Khyber Pakhtunkhwa, Pakistan.
In light of the reports from Technavio [11], the global market of all light vehicles such as golf carts is dominated by the lead acid batteries about $99 \%$ a decade ago to about $86 \%$ in 2018 and is forecasted to reach up to $\$ 65$ billion by 2022 . However, the golf carts market has seen a surge in using the lithium-ion batteries. Since, the lithium-ion batteries are more efficient, maintenance free, and having better life cycle enabling them attractive for future use in automobiles. In this context, the dominance of the lead acid batteries in light vehicles is forecasted to sink further and available for basic electrification as more and more lithium-ion batteries are deployed for traction purposes of light vehicles [12]

The chemical energy stored in a lead acid battery can be translated into reversible electrical energy [13]. This enables this simple battery-rechargeable, as indicated by (1).

$$
\mathrm{P}_{\mathrm{b}}+\mathrm{P}_{\mathrm{b}} \mathrm{O}_{2}+2 \mathrm{H}_{2} \mathrm{SO}_{4} \mathrm{P}_{\mathrm{b}} \leftrightarrow 2 \mathrm{P}_{\mathrm{b}} \mathrm{SO}_{4}+2 \mathrm{H}_{2} \mathrm{O}
$$

whereas, the rate of chemical reaction changes with: (i) battery storage capacity, stage of charge, temperature, and ageing.

The simple inner chemistry had enabled this technology to be assembled even at local level. Simple refurbish techniques [14] had enabled the technology more attractive to the poor. However, due to the increased demand, the characterization of used lead acid batteries in bulk is still time consuming, laborintensive, and unreliable [15]. All of these, and until now, as compared to other storage options, lead acid technology is mature enough to dominate the transportation and basic electrification needs at much affordable cost [16].

The huge growth of battery markets [17] in the $20^{\text {th }}$ century (eventually consuming about $75 \%$ of the world's lead production) largely paralleled the rise of the automobile, in which batteries found application for starting, lighting, and ignition (SLI) (the SLI battery), and uninterruptible power supplies in homes, shops, clinics, markets, and public places.

In parallel, the operation of PV or hybrid PV based micro/nanogrids using lead acid batteries for rural electrification is trending at least until the availability of the affordable second life lithium-ion batteries by 2025 . The goal of electrifying the last billion will significantly demand an increased amount of the second life lead acid batteries for offgrid electrification purposes. Interestingly, the lead acid batteries are the mature and cheapest storage option, that will 
continue to have a hold on their use for the basic electrification. Lead acid batteries for their second life service are readily available at much cheaper cost by decommissioning them from millions of light vehicles such as forklifts or golf carts. The main goal of this paper is to present highly reliable, less labor intensive method for bulk test and restoration of second life lead acid batteries using readily available tools. The proposed method is effective in qualification of the legacy for re-deploying in off-grid electrification, or vendor hand-carts.

The rest of the paper is organized as follows: Section II explains the role of legacy and low cost storage batteries for electrification in more detail. Section III details the innermechanism of lead acid battery and highlights the basic action inside an electrolyte. In Section IV, the bulk characterization and test techniques are presented. Finally, Section V contributes to the main large scale experimental test setup and methods of restoration of lead acid batteries. Also, based on the obtained results, a concluding statement and possible future work is given in Section VI.

\section{ROLE OF LEGACY BATTERIES FOR LOW COST OFF-GRID ELECTRIFICATION}

World over the economic growth is driven by energy; either in the form of finite resources such as coal, oil, and gas or in renewable forms such as hydropower, wind, solar, and biomass, or their converted form; the electric power. This energy generation and consumption powers a nation's industries, vehicles, homes, and offices. It also has a significant impact on quality of the country's air, water, land, and forest resources. For growth to be sustainable, it must be both resource efficient and environmentally-safe. In most of the developing countries, like in Asia and Africa, the demand for electricity has always been more than the supply. This is the reason that most of the people living in rural areas and even the far flung cities face significant power cut.

People with unemployment due to limited energy access is a potential threat to global security. To start even a local small scale business need access to reliable energy to power-up at least an LED bulb for lighting purposes. The significant demand for household electrification and vendor hand-carts have find its way in use of legacy lead acid batteries using minimum cost on restoration. As, most of the local business activities and market visits starts by the evening, thus, keeping in view so, thousands of used car batteries up to capacities of $60 \mathrm{Ah}$ have been deployed in the city circle of district Mardan for electrification of vendor hand-carts as shown in Fig. 1.

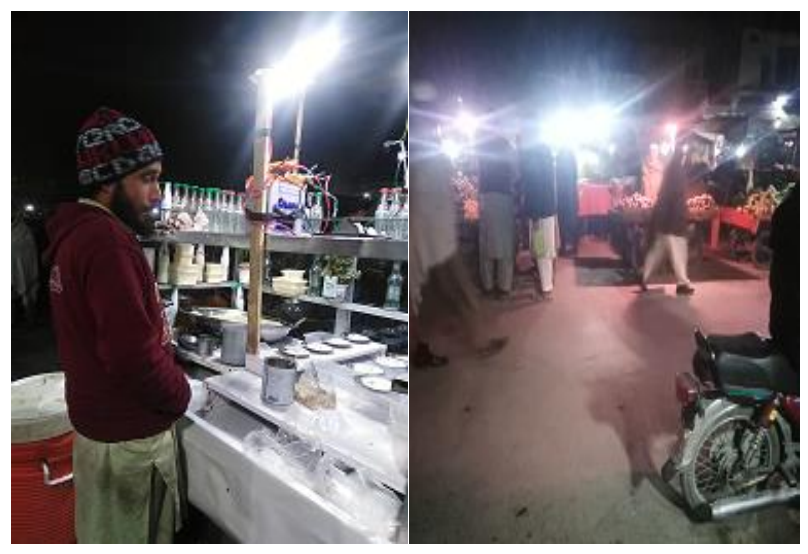

Fig. 1. Electrification of the thousands of vendor hand-carts and local shops using repurposed batteries in Mardan district, Pakistan

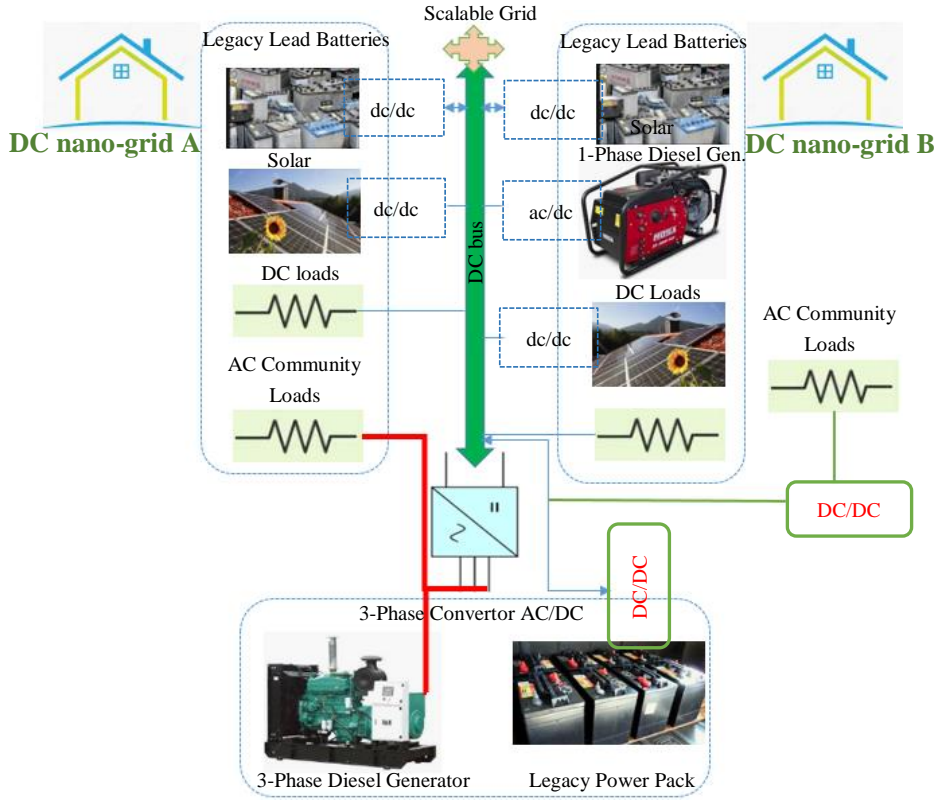

Fig. 2. Illustration showing the topology of the hybridized diesel renewable based clustered microgrid with decentralized control scheme using local measurements; second life lead acid batteries in nanogrid clusters and in back-up microgrid

Increasing attention to the global climate change and the sustainable development open new applications for off-grid renewable or hybrid renewable systems. Off-grid hybrid power systems (PV and diesel generator sets) such as the one shown in Fig. 2, that uses lead acid batteries remain an active practice, but in parallel a bit challenging one. The standalone microgrids are being frequently deployed not only for households, but for commercial facilities like market shops, rural banks, municipal hospitals, and gas stations where power supply is unreliable, limited, or of poor quality. Batteries plays an important role to back-up the load in all of the above mentioned cases.

The legacy batteries can be regrouped in power packs based upon their state of health and capacity. The power packs may be average, below or above average, and the best one. It is always desirable to avoid batteries from extreme operational environment that can quickly exhaust the batteries and result in system collapse. As an example, during the low load demand the weak battery power pack can be engaged to handle it. The fresh batteries are to be engaged in case of peak demand. This enable the battery packs life cycles longer and ensure the system safe from voltage collapse.

The use of legacy batteries in power packs is of particular interest as it also eliminates the circulating current caused by connecting batteries with different health and capacities together. Power packs are individually isolated from the DC bus using dedicated DC/DC convertors as reflected in Fig. 2 .

\section{INNER CHEMISTRY OF THE LEAD ACID BATTERY}

Lead acid batteries consist of several cells, also called accumulators. The nominal voltage of a cell is $2 \mathrm{~V}$. These cells are connected in series configuration to obtain the expected voltage for a variety of applications. The 2 volt cell is the basic unit of a lead acid battery. It consists of an alternately gathered group of positive plates whose active material is $\left(\mathrm{PbO}_{2}\right)$ and negative plates $(\mathrm{Pb})$. The number of plates of each polarity and their dimensions are the main parameters that define the cell capacity. In order to avoid short circuits between the different polarity plates, an insulating micro-porous separator is placed 
between these plates during assembling process. Positive plates are put together in pack as well as negative plates. These are illustrated in Fig. 3. Further, an assembled cross-sectional detail is as depicted in Fig. 4. No matter, what the function is planned for, commonly, the lead acid battery consists the essential components as depicted in Fig. 4. The positive and negative packs are then grouped together and finally put in a container filled with an electrolyte.

All of these, i.e. packs of negative and positive plates, electrolyte, and container, form a cell. The electrolyte is a solution of sulfuric acid and distilled water. The container is generally made of polystyrene. The container has to keep the acid within the cell and at the same time provides mechanical support to the battery. It is designed in a variety of ways to prevent leakage and dry-out while allowing accumulated gases to escape easily through vent plugs. The two terminals made of lead metal connected with the pack of each polarity allow the connection to an external circuit.

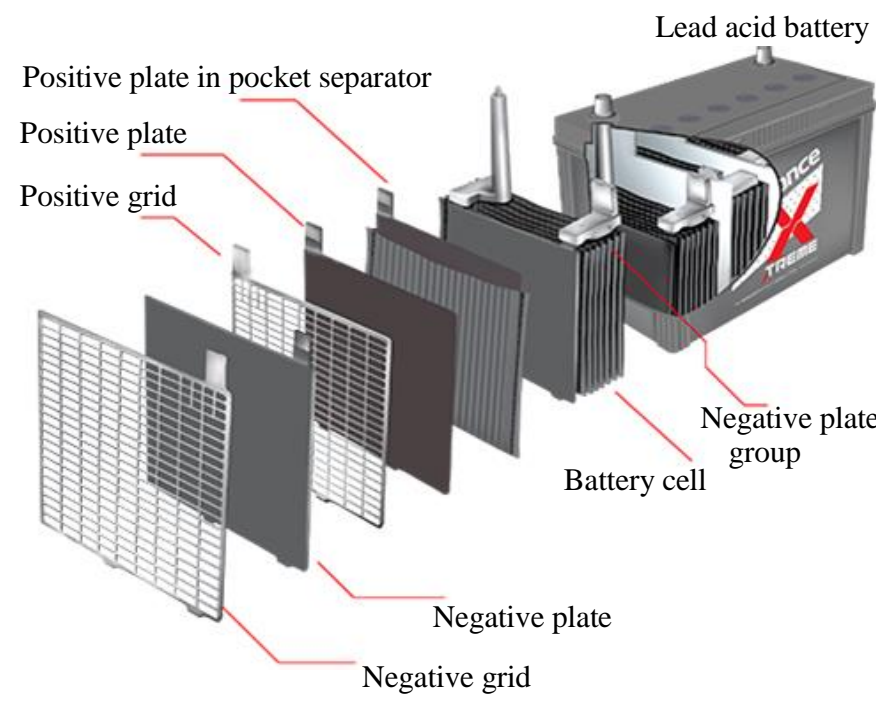

Fig. 3. Schematic representation of a flooded lead acid battery [18]

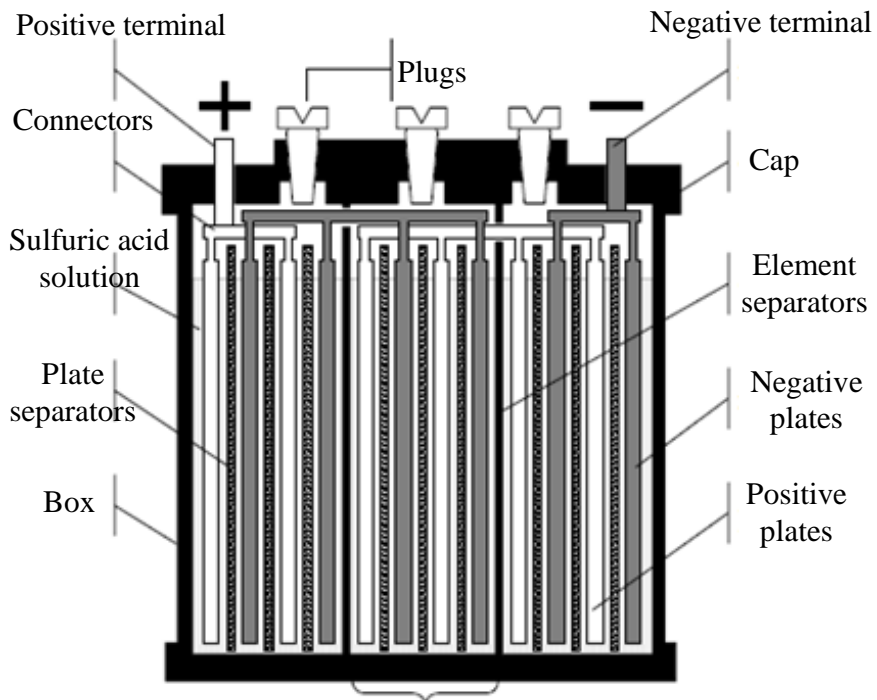

Battery element

Fig. 4. An assembled cross sectional view of the lead acid battery with positive/negative plates, electrolyte, and additional accessories [19]

\section{Bulk CHARACTERIZATION AND Test PROCEDURE}

Some of the most widely known battery parameters are: battery and cell voltages, environment and cell temperatures, battery cell current, and (for flooded cells) cell fluid level, and specific gravity. Less well-known are: cell internal resistances, cell connection resistances, ripple current, cell maintenance current, cell voltage oscillation, and cell selfdischarge that is also strongly dependent on temperature.

Resistive current-path segment is a condition in which some portion of the current path through the battery becomes overly resistive. In such event, i.e. discharge coincidentally, the flow of bank float current will cause excessive voltage drop across the impairment, and in some cases, the resulting ' ${ }^{2} \mathrm{R}^{\prime}$ heating power loss at the defect will initiate thermal runaway leading to melting, arcing (from $L d v / d t$ effects), and (potentially) explosion. Adverse environment is a condition in which the battery is frequently subjected to thermochemical stresses that will inexorably diminish its capacity, reliability, and life. Improper charger voltage is a condition in which the battery is being either over or undercharged because the charger voltage has not been set equal to the manufacturer's prescribed cell voltage multiplied by the number of cells in the bank. Specific gravity test is important as if the temperature corrected specific gravity is more than 15 points below the manufacturer's specified value, then the battery may not be receiving adequate charge or an individual cell may be damaged or not functioning properly.

In summary, if the measured capacity is more than $80 \%$ of the manufacturer's specification and there are no low cell voltages and/or specific gravities, then the battery and the charging parameters are probably acceptable. If measured capacity is significantly below specifications, then a re-test should be considered to determine if the battery replacement is necessary, and/or if the battery charging/discharging scheme needs to be modified.

\section{A. Capacity rating and $C$ (Charge/Discharge) Rate:}

Stationary batteries are rated for a particular capacity in terms of Ampere-hour (Ah) normally at $\mathrm{C}_{10}$ (10-hour rate of discharge), that is a battery rated at $100 \mathrm{Ah}$ will provide $10 \mathrm{~A}$ for 10 hours or $100 \%$ of its capacity at 10 -hr rate of discharge. Table-I indicates the approx. output as a '\%' of $\mathrm{C}_{10}$ capacity.

TABLE I. BAttery OUtPut CAPACITY AS A PERCENTAge of $\mathrm{C}_{10}$

\begin{tabular}{|c|c|c|c|}
\hline $\begin{array}{c}\text { Max. } \\
\text { Discharge } \\
\text { Duration in } \\
\text { Hours for } \\
\begin{array}{c}\text { Flooded } \\
\text { Tubular } \\
\text { Batteries }\end{array}\end{array}$ & $\begin{array}{c}\text { Max. Discharge } \\
\text { Duration in } \\
\text { Hours for Valve } \\
\text { Regulated Lead } \\
\text { Acid Batteries } \\
\text { (VRLA) }\end{array}$ & $\begin{array}{c}\text { Percentage } \\
\text { Output }\end{array}$ & $\begin{array}{c}\text { Current } \\
\text { (Amperes) }\end{array}$ \\
\hline hours & hours & $\%$ & $A$ \\
\hline 10 hours $\left(\mathrm{C}_{10}\right)$ & 10 & 95.0 & 10.0 \\
\hline 08 hours $\left(\mathrm{C}_{8}\right)$ & 8 & 83.3 & 16.7 \\
\hline 05 hours $\left(\mathrm{C}_{5}\right)$ & 5 & 78.2 & 19.5 \\
\hline 04 hours $\left(\mathrm{C}_{4}\right)$ & 3 & 71.7 & 24.0 \\
\hline 03 hours $\left(\mathrm{C}_{3}\right)$ & 2 & 63.3 & 31.5 \\
\hline 02 hours $\left(\mathrm{C}_{2}\right)$ & 1 & 50.0 & 50.0 \\
\hline 01 hours $\left(\mathrm{C}_{1}\right)$ & & & \\
\hline
\end{tabular}


Further, at any higher rate of discharge, the output will be less than the rated output in Ah. Conversely, at the lower discharge rates, the output will be higher than the rated output at $\mathrm{C}_{10}$.

\section{B. Self-Discharge Loss / Retention of Charge (ROC):}

All types of batteries when unused and off-shelf, discharge slowly, but continuously by a phenomenon called selfdischarge [20]. This energy loss is due to local action inside the battery that depends on level of minute impurities in battery elements and accuracy of manufacturing process control. Also, a substantial rise in the operating temperature is an external factor which increases the self-discharge loss. The self-discharge loss is measured by ROC test which determines the amount of charge retained by a battery after free standing for 28 days at a standard temperature of $20 \mathrm{C}^{\circ}$.

The ROC test as per IS:15549 for VRLA batteries and IS:13369 for flooded tubular mono-block new batteries [21] accepts self-discharge loss within $10 \%$ and $5 \%$, respectively. Customer can safely ascertain that the quality of material used and the manufacturing process control are good, simply by ensuring that the batteries meet the ROC limits. A battery with poor ROC can have multiple deficiencies (by way of raw material input or manufacturing defects) inside and the selfdischarge loss can grow by 3 or 4 times over the period of the battery useful lifetime.

\section{METHOdOLOGY OF RESTORING THE USEFUl CAPACITY OF SECOND LIFE BATTERIES AND EXPERIMENTAL SETUP}

Once the used batteries in bulk are received at the workshop, some less labor intensive and quick procedure is used to regroup the batteries for later decision on their suitability to be reused or recycled. In Step 1, the collected or decommissioned batteries are sorted and passed through physical inspection. If the physical inspection is passed, then in Step 2, the batteries are passed through another test to determine the sulfated or shorted cells. Finally, in Step 3, the batteries are qualified to regroup in battery power packs based on their remaining useful capacity and health. It is to note that battery power pack is an assembled pack to reach a certain voltage, current handling capability, and power rating.

The battery power packs may be of very good, above average, average, or weak back-up capabilities that rely on their state of health and capacity. The battery packs serve an important role to handle the light and heavy loads in the form of individual groups or they could be charged discharged independently from the common bus to eliminate the internal discharge or circulating currents due to mismatch in the innerresistance of the battery plates. This is of particular interest especially in the microgrid scenario where the load is normally fed in tiers i.e. from low load such as general lighting, phone charging, air circulation, laptops, or television $(\sim 50 \mathrm{~W})$ to the average and high loads including community lighting and electric fans $(\sim 200 \mathrm{~W})$, all in the residual capacity of the repurposed used batteries.

\section{A. Physical Inspection and Initial Tests:}

\section{1) Sorting}

These tests are the easiest, less labor intensive, and much quicker one i.e. the (i) Open Circuit Voltage (OCV) test (ii) terminal condition (iii) color of plates (iv) color of vent plugs and (v) the specific gravity of electrolyte. This is the best way to start for physical inspection. Due to electrolyte stratification most of the lead acid batteries do not accept charge from low current sources such as solar. In this test, if any of the battery voltage is below $6 \mathrm{~V}$ it is considered as completely dead and scrapped for lead recycling. It also indicates that if three or more cells are completely dead, then their refurbishment cost will be high. The battery terminal condition will quickly indicate the usage of battery. The plates color indicates the wear and tear and its chances of recovery. The color of vent plugs is a quick way of indication of the battery health. If it is black, the cells are in extreme wear and tear condition. The electrolyte had to be spilled-out and washed completely to remove the contaminations. After a satisfactory visual inspection, if everything appeared to be normal, the additional tests are carried out as follows.

\section{2) Specific Gravity Test}

Hydrometer, that is available in the market for nearly $\$ 1 \sim 2$ can rapidly identify the battery condition. If the gravity of all the cells is uniform and low it means that battery is completely recoverable, only it is low on charge or was deeply discharged.

\section{3) Individual Cell Test}

It is possible that a battery passes all of the above tests, however, one test is necessary to identify the individual cell voltage. This can be done using multimeter probes dipped in the electrolyte one by one. The fully discharged cell indicates $\sim 1.75 \mathrm{~V}$ while the dead cell will show much less than that. The equation that best characterizes a cell is given as (2).

$$
\left\{\begin{array}{c}
I=P_{\text {cell }} / V \\
C_{b}(O C V) \cdot \frac{d(O C V)}{d t} \\
O C V(S O C)+R_{\text {int }}(S O C) . I
\end{array}\right.
$$

Where, $I, P_{\text {cell }}, V, R_{\text {int }}$, and $S O C$ are the individual cell's current, power, voltage, internal resistance, and state of charge, respectively. Also, $C_{b}$ represents the battery capacity in RC equivalent model capacitance in series with $R_{\text {int }}$.

\section{4) Light Load Test}

This test is necessary before qualifying the battery for power packs. This load test can be done with a $100 \mathrm{~W}$ bulb connected through a cheap invertor. If the voltage drops by more than $1 \mathrm{~V}$, every cell may be tested for their cell voltage.

\section{5) Sulfated, Open, or Shorted Cells Tests}

This is one of the easiest and fastest method of identifying the faulty cells using a short circuit between battery terminals for 10 seconds. Cell with no bubbles or few bubbles is hard sulfated; with reasonable bubbles are normal; and with boiling and gasification, is shorted. The hard sulfated cells can be recovered, however, shorted cells are to be refurbished as any of the recovery techniques with a shorted cell is waste of time.

The sulfation test is basically a high load test to obtain the information the way a battery gets fully discharged or accept charge. Use a conventional charger/invertor with lower cutoff voltage set at $10.8 \mathrm{~V}$. Note down the time and compare the voltage on load with the open circuit voltage. The fair good indication of a sulfation that causing much higher internal resistance is that the battery will have much lower amperage capacity at a high load test. When the load is removed the battery OCV suddenly bumps up to roughly above $12 \mathrm{~V}$. 


\section{6) Battery Charging Response Test}

This test is carried out for batteries having no shorted cells as could be identified from the Test 5 . The battery voltage with hard sulfation will quickly rise and the charger will shut down. If the battery is fine, the battery sulfation dissolves into electrolyte and the battery voltage will keep fall under charge condition that indicates that the battery is accepting charge. These are illustrated in Fig. 5 and Fig. 6, respectively.

\section{B. Battery Reconditioning and Recovery:}

After the batteries have qualified for reconditioning and recovery process, the following method has been proposed.

\section{1) Heavy Cycling Method of Restoration}

The thrown away or decommissioned batteries can be put to toxic lead recycling to get a new battery, but it won't be a favor to the environment. It has been observed that majority of the discarded batteries for whatever reasons, do not accept charge even for a very long time or the charging system refuse to charge these old batteries due to thick sulfation on the lead plates. These lead sulfate crystals resist to the flow of current and it is the number one cause of the failure of lead acid batteries. Such batteries have no amperage capacity and they exhaust within an unexpected short time. It is because the battery remained un-charged for an indefinite time and hence heavily sulfated due to electrolyte stratification. Interestingly, these batteries are recoverable using heavy cycling method.

The proposed heavy cycling method relies on overcharging using an archaic cheap dumb charger and to deep discharge using a heavy load of amperage of at least twice the battery $\mathrm{C}_{10}$ discharge capacity in controlled manner. In this case, $20 \mathrm{~A}(240 \mathrm{~W} / 12 \mathrm{~V})$ load is a good number that is twice that of the 100Ah discharge capacity of the battery. This way the plates breath and the crystals break down turning back into proper kind of lead raising the acid concentration in the battery. This allows to pass current through these plates from chemical reaction. The battery electrolyte will get boiled and outgassing, but that's normal and also it's an indication of the job going pretty well. Though, there are other techniques that sound good to non-technical people who like to believe them, but there's nothing behind such market snake-oil techniques like putting Aspirin, Baking soda, or Epsom salt in each cell. If these would have worked, the battery manufacturers could benefit by adding Epsom salt, they would do so, but they don't.

Since, the microcontroller based or standard smart charger won't desulfate batteries, as it simply won't go up for a while due to low voltage of the used battery. In this case a standard dumb old charger consists of a transformer and rectifier best fit for the cycling to break majority of the irreversible sulfates from the battery plates. These crystals will get settled down as a result of breathing by the battery plates during heavy cycling. However, due to overcharge a standard automotive light should be used in series to avoid boiling of the electrolyte for sealed Absorbed Glass Mat (AGM) batteries or to pop the vents up for flooded lead acid batteries. It is recommended to use a variable auto-transformer to crank the voltage of the charger a little bit down during the overcharge condition.

In this process, it is observed that during the first cycling, the battery didn't last very long, but that's normal. The dumb charger was hooked up again for the next heavy charge cycle and the readings in Table-II were observed. This indicates that the battery is recovering and the useable capacity is increasing as indicated by increase in charge acceptance.
TABLE II. HEAVY CYCLING FOR DESULFATION AND RECOVERY

\begin{tabular}{|c|c|c|c|c|c|c|}
\hline 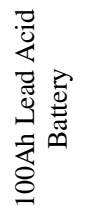 & 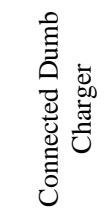 & 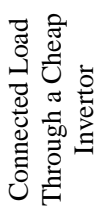 & 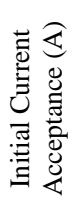 & 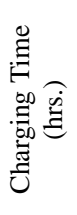 & 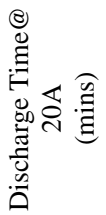 & 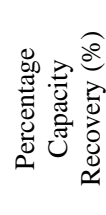 \\
\hline Cycle 1 & $16 \mathrm{~V} / 6 \mathrm{~A}$ & $200 \mathrm{~W}$ & 0.1 & 24 & 10 & 3.30 \\
\hline Cycle 2 & $16 \mathrm{~V} / 6 \mathrm{~A}$ & $200 \mathrm{~W}$ & 1.2 & 24 & 30 & 10.0 \\
\hline Cycle 3 & $16 \mathrm{~V} / 6 \mathrm{~A}$ & $200 \mathrm{~W}$ & 2.5 & 24 & 50 & 16.7 \\
\hline Cycle 4 & $16 \mathrm{~V} / 6 \mathrm{~A}$ & $200 \mathrm{~W}$ & 3.3 & 24 & 90 & 30.0 \\
\hline
\end{tabular}

Further, an increased overcharge may easily break sulfation, however, gasses exhausted pretty aggressively causing the acid splattering around. It is observed that during the heavy cycling process more capacity out of these dead batteries has been achieved. It is also observed that at some point after four cycles the capacity recovery stops or increases negligibly. That's done. The battery was put out of the setup and was put back to service with a reasonable life, as in Fig.7.

Finally, there are of course few market snake-oil such as: to break the sulfation by powerful machines in five minutes, or the battery-desulfators, but what they clean out is a person's wallet and not the resistive acid crystals. Epsom salts for the battery recovery is right on the money as well. In a pinch it works, but it's no long term magical fix. These are just debunked methods with no clear scientific validations in white papers and academic research. Though, Epsom salts can give a few more months of battery life for very little effort, but accelerated self-discharge, plate corrosion prevents using these in the technical context for long lasting second life service.

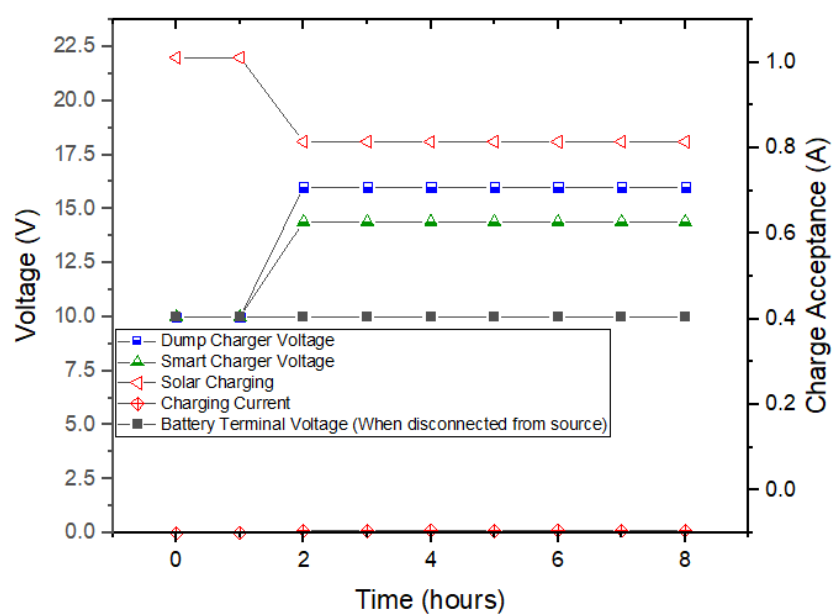

Fig. 5. Charge acceptance response of a completely sulfated battery

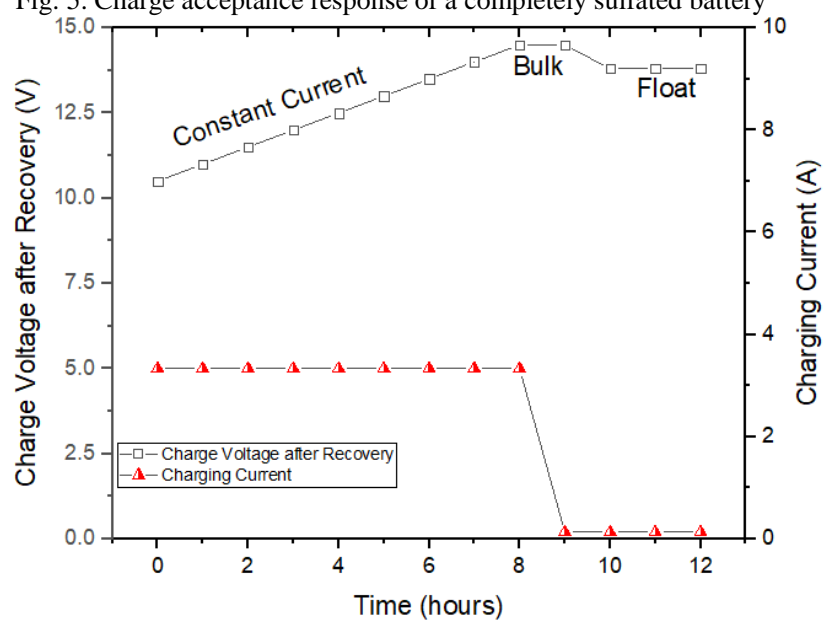

Fig. 6. Charge acceptance after de-sulfation process 


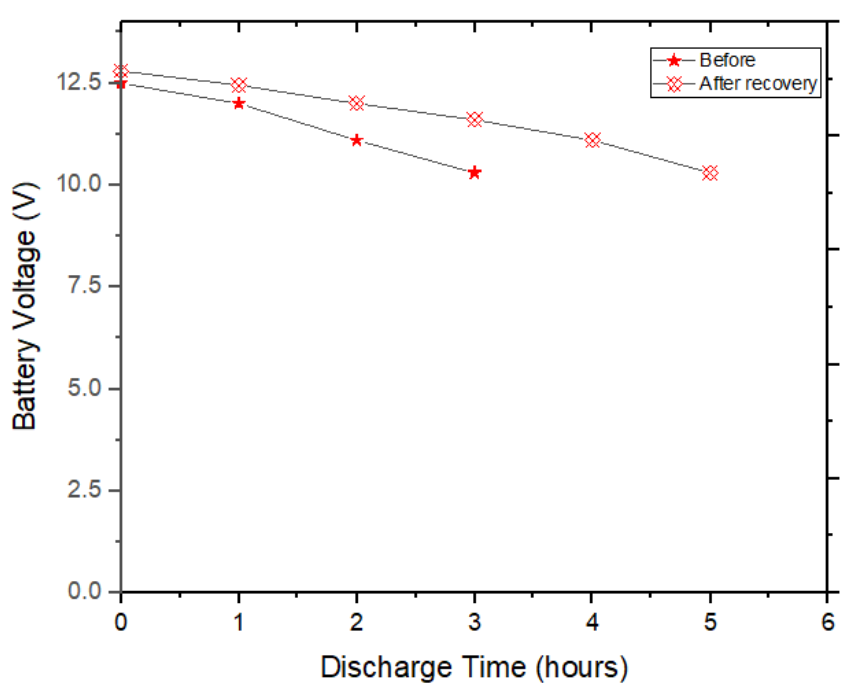

Fig. 7. Recovery state of the used battery capacity using heavy cycling

This concludes our work that the lead acid batteries are mostly recoverable with simple test and restoration techniques. The highly sulfated battery in this case had initially refused to accept charge due to intact acid crystals on lead plates. They were cracked-down using slight overcharging by the dump charger and discharged through heavy load for few cycles. The standard charger can't be used in this application as it will turn-off as the voltage bumps up in the initial stage.

\section{CONCLUSION}

Discussion on lowering the storage cost of the off-grid electrification for rural communities is pretty much spot on. Every year, millions of batteries are thrown away or junked due to a condition called-sulfation, that is recoverable. This paper had covered giving the second life of service to dead lead acid batteries using simple, quick, and low budget methods of restoring the capacity using the heavy cycling process. The second life service of batteries had proven to be better on the path of green theme than being thrown away for recycling. In the context of the off-grid electrification, the repurposed batteries had been trialed on many vendor handcarts and microgrid electrification purposes and an overall satisfactory response has been observed. Results have shown that thousands of vendor hand-carts, shops, and remote houses can be powered easily using such batteries. In doing so, they can delay the recycling process and extend the useful lifetime up to 3-4 years with reasonable capacity, thereby, obtaining new revenues and contribute to the green environment.

Future work will particularly encompass more quick and reliable measurement methods in bulk for different installations and different used battery models. In order to extend the second life, a super capacitor based hybrid storage will be modeled and analyzed for an efficient and extended performance in off-grid electrification systems.

\section{ACKNOWLEDGMENT}

Special thanks to Dr. Imran Khan, the AIT Thailand alumnus and Professor in the Department of Electrical Engineering, University of Engineering \& Technology Mardan, Pakistan for his valuable comments and feedback. Also, discussions with several colleagues were valuable in clarifying some of the thoughts given here, for which we are grateful.

\section{REFERENCES}

[1] World Energy Outlook, Electricity Access, 2016. Available: http://www.worldenergyoutlook.org/resources/energydevelopment/en erg yaccessdatabase/ [Online], Accessed on Dec. 05, 2019

[2] H. U. R. Habib, S. Wang, M. R. Elkadeem and M. F. Elmorshedy, "Design Optimization and Model Predictive Control of a Standalone Hybrid Renewable Energy System: A Case Study on a Small Residential Load in Pakistan," in IEEE Access, vol. 7, pp. 117369117390, 2019.

[3] https://www.iea.org/topics/energy-access/,[Online] https://trackingsdg7.esmap.org/ [Online], Accessed on Jan. 07, 2020.

[4] M. Nasir, H. A. Khan, A. Hussain, L. Mateen and N. A. Zaffar, "Solar PV-Based Scalable DC Microgrid for Rural Electrification in Developing Regions," in IEEE Transactions on Sustainable Energy, vol. 9, no. 1, pp. 390-399, Jan. 2018

[5] A. Berizzi, M. Delfanti, D. Falabretti, S. Mandelli and M. Merlo, "Electrification Processes in Developing Countries: Grid Expansion, Microgrids, and Regulatory Framework," Journal Articale in Proceedings of the IEEE, vol. 107, no. 9, pp. 1981-1994, Sept. 2019.

[6] A. Kumar, A. R. Singh, Y. Deng, X. He, P. Kumar and R. C. Bansal, "A Novel Methodological Framework for the Design of Sustainable Rural Microgrid for Developing Nations," in IEEE Access, vol. 6, pp. 24925-24951, 2018

[7] A. A. Eajal, A. H. Yazdavar, E. F. El-Saadany and K. Ponnambalam, "On the Existence of Voltage Collapse in Islanded Microgrid," 2018 IEEE Electrical Power and Energy Conference (EPEC'2018), Toronto, pp. 1-6, 2018.

[8] IEEE Approved Draft Recommended Practice for Sizing Lead-Acid Batteries for Stand-Alone Photovoltaic (PV) Systems," in IEEE Standards, P1013/D1.3, pp.1-54, $21^{\text {st }}$ May 2019.

[9] M. Mohsin, A. Picot and P. Maussion, "Lead-acid battery modelling in perspective of ageing: a review," 2019 IEEE 12th International Symposium on Diagnostics for Electrical Machines, Power Electronics and Drives (SDEMPED'19), Toulouse, France, pp. 425-431, 2019.

[10] J. Dulout and L. F. L. Villa, "Working towards greener golf carts - A study on the second life of lead-acid batteries," 2019 Fourteenth International Conference on Ecological Vehicles and Renewable Energies (EVER'19), Monte-Carlo, Monaco, pp. 1-5, 2019.

[11] https://www.technavio.com/report/advanced-lead-acid-batterymarket-industry-analysis/ [Online], Accessed on Dec. 03, 2019

[12] M. Ceraolo, T. Huria, G. Pede, F. Vellucci, "Lithium-ion startinglighting-ignition batteries: Examining the feasibility," in Proceedings of Vehicle Power and Propulsion Conference (VPPC'2011), pp. 1-6, 10.1109/VPPC.2011.6043116, Oct. 2011.

[13] H. W. Morse, Storage Batteries, MacMillan Co., New York, 1912.

[14] P.B. Krandikar, "Review on desulfation of lead-acid battery for HEV," Int. J. Current. Eng. Sci. Res., vol. (2), pp. 85-96, 2015.

[15] IEEE Guide for Selecting, Charging, Testing, and Evaluating LeadAcid Batteries Used in Stand-Alone Photovoltaic (PV) Systems," in IEEE Std. 1361-2014, (Revision of IEEE Std. 1361-2003), pp.1-39, $16^{\text {th }}$ June 2014.

[16] M. Nasir, S. Iqbal and H. A. Khan, "Optimal Planning and Design of Low-Voltage Low-Power Solar DC Microgrids," in IEEE Transactions on Power Systems, vol. 33, no. 3, pp. 2919-2928, May 2018.

[17] P. Shah, "Automotive Battery Market Outlook, Share, Size Growth, Business Report and Future Prospects, 2024,"10.13140 RG.2.2.34715.00808, Nov. 2019.

[18] https://www.varta.com/ [Online], Accessed on Nov. 30, 2019

[19] "Technical Guidelines for the Environmentally Sound Management of Waste Lead-acid Batteries", 2003, Basel Convention series/SBC No. 2003/9, ISBN : 92-1-158627-5, 2003.

[20] F. Al-Jabarti, A. Al-Mutairi, and A. Al-Harbi, "Data Center Flooded Lead Acid Battery Early Degradation Causes, Analysis, and Mitigation," In Proceedings of IEEE Int. Telecommunications Energy Conference (INTELEC'18), Turin, pp. 1-4, 2018.

[21] Bureau of Indian Standards "IS:15549 Stationary valve regulated lead acid batteries" Standards for Stationery Batteries, New Delhi, 2005. 